IFN Working Paper No. 891, 2011

\title{
The WTO Dispute Settlement System 1995-2010: Some Descriptive Statistics
}

Henrik Horn, Louise Johannesson and Petros C. Mavroidis 


\title{
The WTO Dispute Settlement System 1995-2010: Some Descriptive Statistics
}

\author{
by \\ Henrik Horn*, Louise Johannesson**, and Petros C. Mavroidis***
}

16 November 2011

Forthcoming Journal of WORLD TRADE 45(6), 2011

\begin{abstract}
* Professor of International Economics. Senior Research Fellow at The Research Institute of Industrial Economics (IFN), Stockholm, Non-resident Senior Fellow at Bruegel, Brussels, and Research Fellow at the Centre for Economic Policy Research, London. We are grateful for financial support from Riksbankens Jubileumsfond.

** The Research Institute of Industrial Economics (IFN), Stockholm.

*** Edwin B. Parker Professor of Law, Columbia Law School, New York; Faculty of Law, and University of Neuchâtel..
\end{abstract}

This is an updated version of the paper The WTO Dispute Settlement System 1995-2006: Some Descriptive Statistics” (2007). 


\section{Introduction}

This paper reports descriptive statistics based on the WTO Dispute Settlement Data Set (Ver. 3.0). The data set contains approximately 67000 observations on a wide range of aspects of the Dispute Settlement (DS) system, and is exclusively based on official WTO documents. It covers all 426 WTO disputes initiated through the official filing of a Request for Consultations from January 1, 1995, until August 11, 2011, and for these disputes it includes events occurring until July 28, 2011. ${ }^{1}$ In this paper however, we will omit data pertaining to 2011 and only consider the full years 1995-2010.

In order to shed some light on differences across WTO Members in participation in the DS system, we will divide Members into five groups, as specified in detail in Table 1. Broadly speaking, these groups are:

- G2: The European Union (EU), and the United States (US)

- IND: Other industrialized countries

- DEV: Developing countries other than LDC

- LDC: Least developed countries

- BIC: Brazil, India and China.

The EU is taken to be EU-15, since the enlargements came relatively late during the period we cover. For the most part, the choice in this regard makes little difference quantitatively, since most of the 12 countries acceding to the EU in 2004 and 2007 have been relatively inactive in the WTO. The LDC group corresponds to the list of LDCs prepared by the United Nations. A more discretionary line is drawn between IND and DEV. We have classified under IND, OECD Members, the non-OECD Members among the 12 countries that most recently became members of the EU, those that are currently at an advanced stage of their accession negotiations, as well as countries that are not OECD Members but have a very high per capita income, such as Singapore. The DEV group consists of all countries which do not fit into either of the above

\footnotetext{
${ }^{1}$ These correspond to disputes DS1-DS426 in terms of the dispute number assigned by the WTO Secretariat when a Request for Consultation is filed.
} 
mentioned categories, and are not BIC countries either. BIC refers to Brazil, India, and China: the sheer number of cases in which Brazil, India and China have participated, as well as their overall participation in WTO, led us to these three countries as a separate group.

The paper is structured as follows: Section 2 highlights the evolution of the total use of the DS system; Section 3 discusses some aspects of participation of the groups defined above when acting as complainants or respondents; Section 4 deals with the subject-matter of disputes; Section 5 highlights a few aspects of countries' success with regard to the legal claims they made before panels; Section 6 provides information as to the nationality and the appointment process of WTO panelists; Section 7 focuses on the duration of dispute settlement procedures at different stages of the adjudication process; Section 8 concludes. 


\section{Table 1: Country classification}

\begin{tabular}{l} 
G2 \\
\hline EU \\
US \\
\hline \\
BIC \\
\hline Brazil \\
China \\
India \\
\hline
\end{tabular}

DEV cont'd

Cape Verde

Chile

Chinese Taipei

Colombia

Congo

Costa Rica

Cuba

IND

Australia

Côte d'Ivoire

Dominica

Bulgaria

Dominican Republic

Canada

Croatia

Cyprus

Czech Republic

Estonia

Hong Kong - China

Hungary

Iceland

Israel

Japan

Korea

Latvia

Liechtenstein

Lithuania

Malta

Mexico

New Zealand

Norway

Poland

Romania

Singapore

Slovak Republic

Slovenia

Switzerland

Turkey

\begin{tabular}{l}
\hline DEV \\
\hline Albania
\end{tabular}

Antigua and Barbuda

Argentina

Armenia

Bahrain

Barbados

Belize

Bolivia

Botswana

Brunei Darussalam

Cameroon
Ecuador

Egypt

El Salvador

Fiji

Former Yugoslav Republic of Macedonia

Gabon

Georgia

Ghana

Grenada

Guatemala

Guyana

Honduras

Indonesia

Jamaica

Jordan

Kenya

Kuwait

Kyrgyz Republic

Macao - China

Malaysia

Mauritius

Moldova

Mongolia

Morocco

Namibia

Nicaragua

Nigeria

Oman

Pakistan

Panama

Papua New Guinea

Paraguay

Peru

Philippines

Qatar

Saint Vincent and the Grenadines

Saudi Arabia

South Africa

Sri Lanka

St Kitts and Nevis

\section{DEV cont'd}

St Lucia

Suriname

Swaziland

Tanzania

Thailand

Tonga

Trinidad and Tobago

Tunisia

Ukraine

United Arab Emirates

Uruguay

Venezuela

Viet Nam

Zimbabwe

LDC

Angola

Bangladesh

Benin

Burkina Faso

Burundi

Cambodia

Central African Republic

Chad

Congo, Democratic Republic of the

Djibouti

Gambia

Guinea

Guinea Bissau

Haiti

Lesotho

Madagascar

Malawi

Maldives

Mali

Mauritania

Mozambique

Myanmar

Nepal

Niger

Rwanda

Senegal

Sierra Leone

Solomon Islands

Tanzania

Togo

Uganda

Zambia 


\section{The use of the DS system}

It is natural to begin by examining the overall use of the DS system during its existence. As can be seen from Figure 1, except for the increase between 1995 and 1996, there has been a pronounced tendency toward fewer complaints for the whole period 1995-2010. The average number of disputes per year was 20 during 2001-2010, whereas it was 36.5 during 1995-2000.

\section{Figure 1: The number of initiated disputes per year}

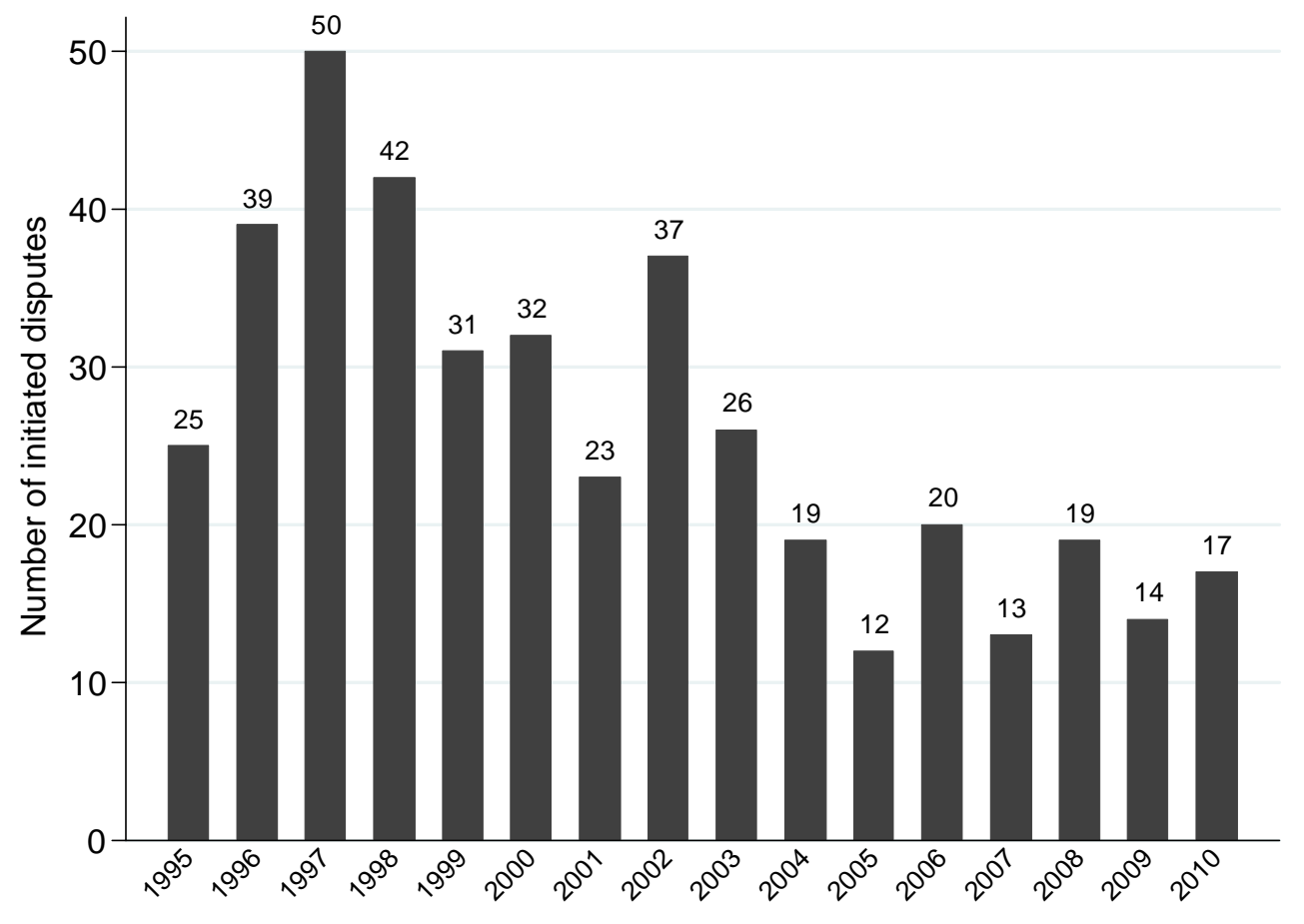




\section{Who are the complainants and respondents?}

Who participates in DS proceedings has received considerable attention in the literature. To address it, it is necessary to define the notion of "a dispute". There are various ways in which this could be done and there is no single correct method applicable across research interests: the appropriate choice depends on the question asked. At the same time, the choice of method may importantly affect the outcome of the investigation, since it effectively defines the unit of account.

The basic idea behind the approach adopted here, as in some literature, is to view disputes between WTO Members at a bilateral level. That is, if two Members are complaining against a third Member, we count each one of them as having a "dispute" with the third Member - we will count, hence, two "bilateral" disputes in this example. Naturally, all original complainants are involved in such bilateral disputes. In many disputes there are also countries that file a Request to Join in Consultations. These countries have clear interest in the dispute, but as a general matter, it is not clear which side they are on. If they are on the side of the original complainant, it is natural to include them among the countries that have a bilateral dispute with the respondent. But it is also possible that they are on the side of the respondent, either because they are pursuing policies that are similar to the challenged one, or because they are in terms of trade structure on the complaining side, but still benefit from the contested measure, or for other reasons. If they are on the side of the respondent one would obviously not want to include the joining countries among those having a dispute with the respondent. In practice, it seems more common that countries that request to join in consultations are on the complaining side. We will follow practice in this respect. But, in Table 2, when we consider requests to join in on consultations, joining Members are specified separately. Also, in Table 3, we examine whether there is any systematic difference with regard to the propensity to join in consultations across country groups.

Table 2: Participation in consultation stage 


\begin{tabular}{|c|c|c|c|c|c|c|c|c|}
\hline $\begin{array}{c}\text { Country } \\
\text { status }\end{array}$ & Complainant & $\mathbf{\%}$ & Third party & $\mathbf{\%}$ & Total & $\mathbf{\%}$ & Respondent & $\mathbf{\%}$ \\
\hline BIC & 51 & 11.4 & 56 & 7.6 & 107 & 9.0 & 55 & 12.3 \\
\hline DEV & 99 & 22.1 & 208 & 28.1 & 307 & 25.9 & 81 & 18.1 \\
\hline G2 & 179 & 40.0 & 143 & 19.3 & 322 & 27.1 & 217 & 48.5 \\
\hline IND & 117 & 26.2 & 328 & 44.3 & 445 & 37.5 & 94 & 21.0 \\
\hline LDC & 1 & 0.2 & 5 & 0.7 & 6 & 0.5 & 0 & 0.0 \\
\hline Total & 447 & 100.0 & 740 & 100.0 & 1187 & 100.0 & 447 & 100.0 \\
\hline
\end{tabular}

Let us start by examining the number of times Members of the five identified groups have initiated disputes. As can be seen from Table 2, the G2 countries have complained 179 times. With a total of 447 bilateral disputes, this implies the G2 accounts for $40 \%$ of the bilateral complaints, making it the most active group. IND is second with 117 (26\%) bilateral complaints, followed by DEV with 99 (22\%) bilateral disputes. BIC comes fourth with 51 (11\%), and last is the group LDC which has complained only 1 time (Bangladesh), that is, in $0.2 \%$ of all bilateral disputes.

When looking at total participation during consultations as complainants or as a third party the IND countries have been most active with 445 of the 1187 total number of appearances 37\%. G2 countries come second with 332 appearances (27\%), and DEV comes in at a close third with 307 appearances (26\%). BIC has a total of 107 (9\%), and LDC has been active 6 times (1\%).

G2 is the most targeted group of countries and its practices have been challenged 217 times (or in $49 \%$ of the cases), so G2 countries act as a complainant or a respondent around every other dispute. IND follows with 94 (21\%), DEV is third with 81 (18\%), and BIC had its practices disputed 51 times (12\%). LDC countries have never acted as respondents.

Finally, comparing participation as complainants and as respondents, we see that the country groups tend to participate as often in both roles. But the two extreme groups in this regard are IND, which more often complains than responds to complaints, and G2, which plays the opposite role of being more targeted by complainants than complaining itself. 
Table 3a: Distribution of bilateral complaints over complainant and respondent groups

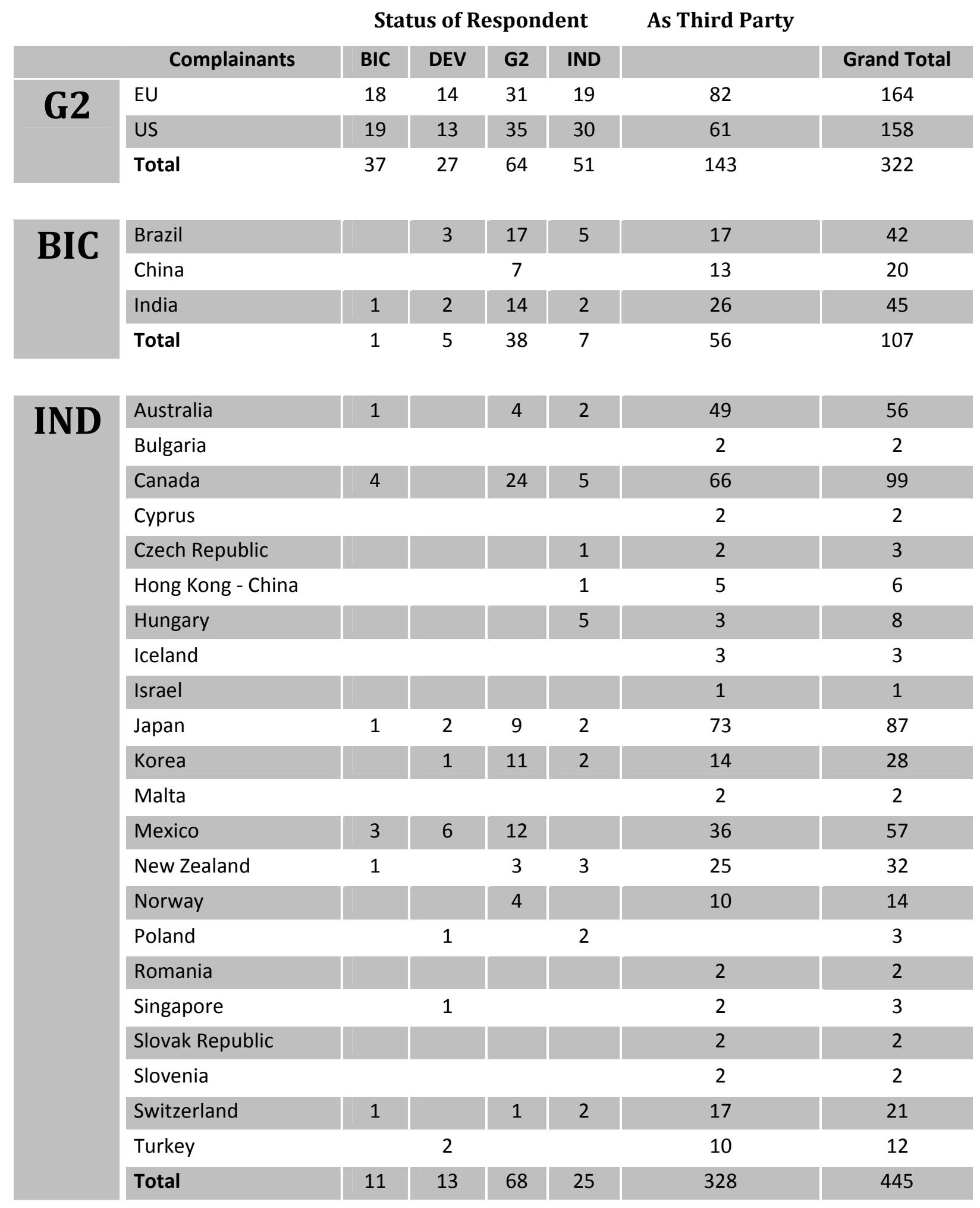




\begin{tabular}{|c|c|c|c|c|c|c|c|}
\hline \multirow{3}{*}{ DEV } & \multirow[b]{2}{*}{ Complainants } & \multicolumn{4}{|c|}{ Status of Respondent } & As Third Party & \multirow[b]{2}{*}{ Grand Total } \\
\hline & & BIC & DEV & G2 & IND & & \\
\hline & Antigua and Barbuda & & & 1 & & & 1 \\
\hline & Argentina & 1 & 7 & 6 & 1 & 12 & 27 \\
\hline & Barbados & & & & & 2 & 2 \\
\hline & Belize & & & & & 3 & 3 \\
\hline & Bolivia & & & & & 1 & 1 \\
\hline & Chile & & 5 & 4 & 1 & 8 & 18 \\
\hline & Chinese Taipei & 1 & & 2 & & 9 & 12 \\
\hline & Colombia & & 3 & 2 & & 16 & 21 \\
\hline & Congo & & & & & 2 & 2 \\
\hline & Costa Rica & & 4 & 1 & & 10 & 15 \\
\hline & Cuba & & & & & 2 & 2 \\
\hline & Côte d'Ivoire & & & & & 3 & 3 \\
\hline & Dominican Republic & & & & & 8 & 8 \\
\hline & Ecuador & & & 2 & 1 & 13 & 16 \\
\hline & El Salvador & & 1 & & & 6 & 7 \\
\hline & Fiji & & & & & 2 & 2 \\
\hline & Guatemala & 1 & 2 & 3 & 2 & 19 & 27 \\
\hline & Guyana & & & & & 2 & 2 \\
\hline & Honduras & & 4 & 3 & & 11 & 18 \\
\hline & Indonesia & & 2 & 2 & 1 & 1 & 6 \\
\hline & Jamaica & & & & & 5 & 5 \\
\hline & Kenya & & & & & 2 & 2 \\
\hline & Malaysia & & & 1 & & 1 & 2 \\
\hline & Mauritius & & & & & 2 & 2 \\
\hline & Nicaragua & & & & 1 & 9 & 10 \\
\hline & Pakistan & & 1 & 2 & & 5 & 8 \\
\hline & Panama & & 2 & 3 & & 7 & 12 \\
\hline & Peru & & 1 & 2 & & 9 & 12 \\
\hline & Philippines & 1 & 1 & 1 & 2 & 6 & 11 \\
\hline & Sri Lanka & 1 & & & & 1 & 2 \\
\hline & St Kitts and Nevis & & & & & 2 & 2 \\
\hline & St Lucia & & & & & 3 & 3 \\
\hline & Swaziland & & & & & 2 & 2 \\
\hline & Thailand & 0 & 2 & 9 & 2 & 16 & 29 \\
\hline & Ukraine & & 1 & & & & 1 \\
\hline & Uruguay & & & 1 & & 1 & 2 \\
\hline & Venezuela & & & 1 & & 4 & 5 \\
\hline & Viet Nam & & & 1 & & & 1 \\
\hline & Zimbabwe & & & & & 3 & \\
\hline & Total & 5 & 36 & 47 & 11 & 208 & 307 \\
\hline \multirow{3}{*}{ LDC } & Bangladesh & 1 & & & & 1 & 2 \\
\hline & Madagascar & & & & & 2 & 2 \\
\hline & Malawi & & & & & 2 & 2 \\
\hline
\end{tabular}




\section{Table 3b: Distribution of bilateral complaints across complainant and respondent groups in \%}

\begin{tabular}{c|c|c|c|c|c|c|} 
& & \multicolumn{5}{c|}{ Respondent } \\
& \% & BIC & DEV & G2 & IND & Total \\
\hline \multirow{4}{*}{ Complainant } & BIC & 2.0 & 9.8 & 74.5 & 13.7 & 100.0 \\
\hline DEV & 5.1 & 36.4 & 47.5 & 11.1 & 100.0 \\
\cline { 2 - 8 } & G2 & 20.7 & 15.1 & 35.8 & 28.5 & 100.0 \\
\hline & IND & 9.4 & 11.1 & 58.1 & 21.4 & 100.0 \\
\hline & LDC & 100.0 & 0.0 & 0.0 & 0.0 & 100.0 \\
\hline
\end{tabular}

We now turn to the question of who targets whom. Table 3a shows the distribution of complainants over the individual Members of the WTO and Table 3b provides summary views of this pattern. It emerges from these Tables that G2 targets chiefly G2 and IND: G2 complaints against G2 constitute 36\% of its total complaints (64 of 179 complaints) and against IND, 29\% (51/179). 21\% of G2 complaints targets BIC countries (37/179) and 15\% are against DEV (27/179).

As can be seen from Table 3b, IND, DEV, and BIC target G2 much more often than they target any other group: 58\% of all IND complaints are directed against G2 (68/117); 48\% of all DEV complaints concern G2 practices (47/99), and finally 75\% of all BIC complaints aim at the G2 countries (38/51) The majority of bilateral disputes involves thus a G2 country as either a complainant or respondent. 


\section{Table 4: Propensity to join complaints rather than to complain}

\begin{tabular}{|c|c|c|c|c|c|}
\hline Complainant & Respondent & $\begin{array}{c}\text { Request for } \\
\text { consultations }\end{array}$ & $\begin{array}{c}\text { Request to join } \\
\text { consultations }\end{array}$ & Total & $\begin{array}{c}\text { Propensity to } \\
\text { join }\end{array}$ \\
\hline \multirow{3}{*}{ BIC } & BIC & 1 & 0 & 1 & 0.0 \\
\hline & DEV & 5 & 1 & 6 & 16.7 \\
\hline \multirow{5}{*}{ DEV } & G2 & 38 & 52 & 90 & 57.8 \\
\hline & IND & 7 & 3 & 10 & 30.0 \\
\hline & BIC & 5 & 12 & 17 & 70.6 \\
\hline \multirow{5}{*}{ G2 } & DEV & 35 & 40 & 75 & 53.3 \\
\hline & G2 & 47 & 143 & 190 & 75.3 \\
\hline & IND & 11 & 9 & 20 & 45.0 \\
\hline & BIC & 36 & 49 & 85 & 57.6 \\
\hline & DEV & 27 & 27 & 54 & 50.0 \\
\hline & G2 & 63 & 34 & 97 & 35.0 \\
\hline & IND & 51 & 32 & 83 & 38.6 \\
\hline & BIC & 11 & 92 & 103 & 89.3 \\
\hline & DEV & 13 & 20 & 33 & 60.6 \\
\hline
\end{tabular}

Table 4 provides information about the extent to which the different groups have become complainants in bilateral disputes by participating in the original Request for Consultations. Here we observe an asymmetry between G2 and the other groups. In complaints against G2 or IND, G2 will more often act as original complainant: only 35\% of all G2 complaints against G2, and $39 \%$ against IND, are cases where G2 joined in consultations. However, in the case of complaints against DEV, G2 has joined in 50\% of its total cases against this group. Hence, the EU and the US seem more proactive in trade disputes against developed economies than other Members, while they more rarely take the initiative to launch a dispute as original complainant against a DEV country. 
DEV countries, on the other hand, have a high propensity to join in when the target is the G2 (in $75 \%$ of all their complaints against G2, DEV joined in consultations). But DEV countries act more often as original complainants when targeting practices of either IND countries or other DEV countries. IND countries consistently join in consultations more frequently than they act as original complainants, no matter who the target group is. Simplifying somewhat, we can hence conclude that IND and DEV countries prefer to join in, whereas the G2 Members prefer to act as original complainants. This observation could provide some ammunition to those arguing participation is also a function of legal capacity (assuming G2 countries have more privileged access to legal resources than IND or DEV). It also seems to give some support to the argument that original participation is a function of access to information, as information is more available to WTO Members with diversified export trade, and wide networks of commercial attachés: this is typically the case of the countries. And of course, it is usually the case that those with diversified exports are also those with well developed legal and administrative support. 


\section{Table 5: Third party participation in panel proceedings}

\begin{tabular}{|c|c|c|}
\hline & Country & Freq. \\
\hline \multirow{3}{*}{ 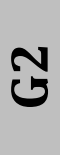 } & EU & 86 \\
\hline & US & 76 \\
\hline & Total & 162 \\
\hline \multirow{16}{*}{$\underline{2}$} & Australia & 57 \\
\hline & Canada & 68 \\
\hline & Hong Kong & 12 \\
\hline & Hungary & 2 \\
\hline & Iceland & 6 \\
\hline & Israel & 3 \\
\hline & Japan & 97 \\
\hline & Korea & 45 \\
\hline & Mexico & 54 \\
\hline & New Zealand & 23 \\
\hline & Norway & 29 \\
\hline & Poland & 1 \\
\hline & Singapore & 7 \\
\hline & Switzerland & 2 \\
\hline & Turkey & 33 \\
\hline & Total & 439 \\
\hline \multirow{4}{*}{$\frac{v}{\infty}$} & Brazil & 54 \\
\hline & China & 64 \\
\hline & India & 62 \\
\hline & Total & 180 \\
\hline \multirow{8}{*}{$\underset{0}{0}$} & Bangladesh & 1 \\
\hline & Benin & 1 \\
\hline & Chad & 1 \\
\hline & Madagascar & 3 \\
\hline & Malawi & 3 \\
\hline & Senegal & 2 \\
\hline & Tanzania & 2 \\
\hline & Total & 13 \\
\hline
\end{tabular}

\begin{tabular}{|c|c|c|c|c|c|}
\hline & Country & Freq. & & Country & Freq. \\
\hline \multirow{32}{*}{$\overrightarrow{0}$} & Argentina & 26 & \multirow{22}{*}{$\vec{P}$} & Pakistan & 5 \\
\hline & Bahrain & 1 & & Panama & 5 \\
\hline & Barbados & 4 & & Paraguay & 13 \\
\hline & Belize & 4 & & Peru & 9 \\
\hline & Bolivia & 1 & & Philippines & 7 \\
\hline & Cameroon & 1 & & Saudi Arabia & 4 \\
\hline & Chile & 24 & & Sri Lanka & 3 \\
\hline & Chinese Taipei & 55 & & St Kitts and Nevis & 3 \\
\hline & Colombia & 27 & & St Lucia & 3 \\
\hline & Costa Rica & 12 & & St Vincent and & . \\
\hline & Cuba & 16 & & the Grenadines & \\
\hline & Côte d'Ivoire & 4 & & Suriname & 1 \\
\hline & Dominica & 3 & & Swaziland & 3 \\
\hline & \multirow{2}{*}{$\begin{array}{c}\text { Dominican } \\
\text { Republic }\end{array}$} & \multirow{2}{*}{3} & & Tanzania & 1 \\
\hline & & & & Thailand & 41 \\
\hline & Ecuador & 12 & & Trinidad and & 2 \\
\hline & Egypt & 3 & & Tobago & \\
\hline & El Salvador & 12 & & Uruguay & 4 \\
\hline & Fiji & 3 & & Venezuela & 17 \\
\hline & Ghana & 1 & & Viet Nam & 8 \\
\hline & Grenada & 1 & & Zimbabwe & 1 \\
\hline & Guatemala & 17 & & Total & 417 \\
\hline & Guyana & 3 & & & \\
\hline & Honduras & 13 & & & \\
\hline & Indonesia & 3 & & & \\
\hline & Jamaica & 7 & & & \\
\hline & Kenya & 3 & & & \\
\hline & Kuwait & 1 & & & \\
\hline & Malaysia & 10 & & & \\
\hline & Mauritius & 5 & & & \\
\hline & Nicaragua & 10 & & & \\
\hline & Nigeria & 1 & & & \\
\hline
\end{tabular}

Table 5 gives data on individual WTO Members' participation as third parties in Panel proceedings. In theory, participation as third parties could be motivated by direct trade interest in the dispute, but also by other reasons: general dissatisfaction with case law in the disputed area; 
disagreements with the manner in which defendant, complainant and/or both argue a particular case; willingness to educate national bureaucracies through 'light' participation in disputes etc. We use the term 'light' participation because third parties, according to the DSU and subsequent DS practice, usually participate only in the first meeting with the panel, do not submit anything in writing, and if they do, they can address whatever they deem appropriate to address. IND emerges as the most often represented group, with 439 of 1211, or 36\%, of all appearances as third parties in all disputes. DEV is close second, with 417 appearances (34\%), followed by BIC with 180 appearances (15\%), G2 with 162 appearances (13\%) and LDC with 13 appearances (1\%). Note that 27 IND countries account for 36\% of all cases, 75 DEV countries for $34 \%$ and only 3 BIC countries, a group situated between the two groups for a disproportionate $15 \%$. This observation ties well with the popular (in WTO circles) idea that Brazil and China especially used third party participation (a 'light' form of participation as argued above) as means to educate their national bureaucracies about the functioning of the WTO DS procedures.

Interestingly, Members across the board have been third parties more often than complainants, and 12 Members have appeared as third parties without having appeared as complainants. It is noteworthy that all of them belong to the DEV/LDC groups (Dominica, Egypt, Ghana, Grenada, Nigeria, Paraguay, Saint Vincent \& the Grenadines, Suriname, Tanzania, Benin, Chad, Senegal).

\section{Which agreements and provisions have been invoked?}

We next turn to the subject-matter of the disputes. We first examine how the total number of disputes is distributed across agreements and provisions for the WTO Membership as a whole. We then turn to see if any broad pattern can be discerned with regard to the matters being raised.

\section{A view across agreements}

Table 6 provides a broad overview of the total number of invocations of GATT with Annexes, GATS with Annexes, and the TRIPs. ${ }^{2}$ In contrast to in Section 3, where we relied on our notion of bilateral complaints, we here use Request for Consultation as our unit of account. An

\footnotetext{
${ }^{2}$ Our abbreviations of official titles of agreements and other decisions appear in the Annex to this paper.
} 
illustration may be warranted: if Art. I GATT, and Art. III GATT have been both invoked in a Request for Consultation, we would count this as one invocation of GATT. Furthermore, we count it as one invocation, irrespective of the number of Members participating in the original Request, and the number of Members joining in at a later stage. Our approach here is justified by the question that we seek to address here: in how many disputes has, say, the GATT been invoked? If both GATT provision(s) and GATS provision(s) are invoked in a dispute, it will in this Table be counted as one GATT invocation and one GATS invocation. Of course, this is by no means the only way in which this could be measured.

\section{Table 6: Number of times the GATT, the GATS and the TRIPs and their Annexes are invoked in Request for Consultations}

\begin{tabular}{ccc}
\hline Agreement & Number of disputes* & \% of total \\
\hline GATT and Annexes & 777 & 94.2 \\
GATS and Annexes & 19 & 2.3 \\
TRIPs & 29 & 3.5 \\
Total & 825 & 100
\end{tabular}

* The GATT Annexes included here are AD, AG, ATC, CV, ILA, ROO, SCM, SG, SPS, TBT, TRIMs, and the Enabling Clause.

As can be seen from Table 6, GATT (and the other Annex 1A agreements, that is the agreements regulating trade in goods) stands for the vast majority of invocations, or $94 \%$ of the total number. There are 50\% more TRIPs invocations than GATS invocations, but they both dwindle in comparison to the invocations of the agreements governing trade in goods. This might prima facie look surprising. However, the fact that developing countries enjoyed a long transitional period to implement TRIPs, probably explains the few invocations of this agreement. GATS is still largely a terra incognita for most trading nations, and it is still debatable whether it has generated any meaningful liberalization in trade in services or whether it still serves mainly as platform for future liberalization: other things equal, one would expect fewer litigations if commitments are shallow than in the opposite case. 


\section{Table 7: Agreements invoked in Requests for Consultations}

\begin{tabular}{|c|c|c|c|}
\hline Agreement & $\begin{array}{c}\text { Invoked in } \\
\text { number of } \\
\text { Requests }\end{array}$ & Percentages & $\begin{array}{c}\text { Percentage } \\
\text { of all } \\
\text { disputes } \\
\end{array}$ \\
\hline GATT & 328 & 36.2 & 78.3 \\
\hline AD & 86 & 9.5 & 20.5 \\
\hline SCM & 86 & 9.5 & 20.5 \\
\hline $\mathbf{A G}$ & 59 & 6.5 & 14.1 \\
\hline TBT & 41 & 4.5 & 9.8 \\
\hline WTO & 41 & 4.5 & 9.8 \\
\hline SG & 39 & 4.3 & 9.3 \\
\hline SPS & 38 & 4.2 & 9.1 \\
\hline ILA & 33 & 3.6 & 7.9 \\
\hline TRIPs & 29 & 3.2 & 6.9 \\
\hline TRIMs & 26 & 2.9 & 6.2 \\
\hline GATS & 19 & 2.1 & 4.5 \\
\hline ATC & 16 & 1.8 & 3.8 \\
\hline ChinaAA & 16 & 1.8 & 3.8 \\
\hline CV & 14 & 1.6 & 3.3 \\
\hline DSU & 11 & 1.2 & 2.6 \\
\hline R00 & 7 & 0.8 & 1.7 \\
\hline AGR & 6 & 0.7 & 1.4 \\
\hline Enabling Clause & 4 & 0.4 & 1.0 \\
\hline GPA & 4 & 0.4 & 1.0 \\
\hline 1979Understanding & 1 & 0.1 & 0.2 \\
\hline MDTruth & 1 & 0.1 & 0.2 \\
\hline WTODecNotProc & 1 & 0.1 & 0.2 \\
\hline Total & 906 & 100.0 & \\
\hline \multicolumn{4}{|c|}{$\begin{array}{l}\text { *The number of times various WTO Agreements have been invoked in Request for } \\
\text { Consultations. No account is taken to how many articles are invoked under each } \\
\text { agreement. This table is to show the prevalence of agreements in Request for } \\
\text { Consultation. Also, no account is taken of the number of complainants in the } \\
\text { dispute. }\end{array}$} \\
\hline
\end{tabular}

Table 7 specifies in more detail the WTO agreements that have been invoked. Not surprisingly, GATT 1947 completely dominates as the most frequently invoked agreement, accounting for roughly a third of all instances. There are then three agreements that between themselves are invoked roughly as frequently, all of them Annex 1A Agreements dealing with trade in goods: 
AD, SCM and AG. But with 9.5\%, 9.5\% and 6.5\%, respectively, they jointly do not stand for more than about a quarter of all invocations.

Tables 8-12 take further steps in disaggregating the data by considering the number of times specific provisions have been invoked. Starting with the use of GATT, Table 8 shows that the basic non-discrimination principles (Arts. I and III of the GATT) have been invoked in 29\% of the disputes (231 out of 794 invocations). They are followed by concerns over alleged quantitative restrictions, which account for $12 \%$ of all GATT disputes (Art. XI, 94/794), and concerns over the lawful imposition of duties, which stand for $11 \%$ of all GATT disputes (Art. II, 84/794) (we disregard Art. XXIII invocations). Consequently, the total number of challenges concerning the legality of trade instruments account for $22 \%$ of all GATT disputes $((94+84) / 794)$. The transparency provision (Art. X GATT) emerges as an important concern as well: in $10 \%$ of all GATT disputes, WTO Members have claimed that had been violated (76/794).

Let us next take a look at other agreements, starting in Table 9 with SCM. Challenges against the legality of subsidies occupied 28\% of all SCM claims (Arts. 3-7, 90 out of 317 claims), whereas, challenges against the legality of imposition of CVDs, 45\% (Arts. 10-23, 142/317). The first category can be further broken down: 17\% of all SCM claims concerned prohibited subsidies (Arts. 3 and 4, 54/317); 11\% concerned actionable subsidies (Arts. 5-7, 36/317). Finally, 16\% of all SCM claims concerned the constitutive elements of the subsidy-definition in the SCM (Arts. 1 and 2, 51/317).

Table 10 provides a breakdown for the $\mathrm{AD}$ agreement. The most frequently invoked provision concern the definition of the dumping margin (Art. 2; 62 invocations; 12\% of all invocations), evidence (Art. 6; 58; 11\%), the investigation (Art. 5; 53; 10\%), injury (Art. 3; 54; 10\%), principles (Art. 1; 52; 10\%), and transparency obligations (Art. 12; 41; 10\%).

Table 11 breaks down invocations of the GATS, showing that its various provisions have been very sparsely invoked. Consequently, it is probably premature to draw any inferences from practice so far. But for what it is worth, we can point to two features: $52 \%$ of all claims concern 
specific commitments (Arts. XVI, XVII and XVIII, 33/64); 41\% of all claims concern alleged violations of the non-discrimination principle (Arts. II and XVII, 26/64), where the National Treatment clause has been invoked almost twice as often as the Most Favored Nation clause.

Finally, the overall number of TRIPs invocations is as noticed above, relatively small. When invoked, the particular provisions mentioned in the Requests for Consultation tend to be remarkably evenly spread across the various provisions of the agreement, as demonstrated in Table 8e. But three provisions stand out as the most frequently invoked: $10 \%$ of all TRIPs claims concern transitional arrangements (Art. 65, 14/ 147), 7\% concern the existing subject matter (Art. 70, 11/ 147), and a further 7\% the patentable subject matter (Art. 27, 10/ 147). 
Table 8: GATT: Number of times invoked in disputes

\begin{tabular}{|c|c|}
\hline \multicolumn{2}{|c|}{ GATT } \\
\hline Article & Frequency* \\
\hline I & 106 \\
\hline II & 84 \\
\hline III & 125 \\
\hline IV & 1 \\
\hline IX & 2 \\
\hline V & 8 \\
\hline VI & 74 \\
\hline VII & 9 \\
\hline VIII & 12 \\
\hline X & 76 \\
\hline XI & 94 \\
\hline XIII & 34 \\
\hline XIX & 38 \\
\hline XV & 2 \\
\hline XVI & 9 \\
\hline XVII & 7 \\
\hline XVIII & 7 \\
\hline XX & 6 \\
\hline XXI & 2 \\
\hline XXIII & 79 \\
\hline XXIV & 8 \\
\hline XXIVInt & 1 \\
\hline XXVIII & 7 \\
\hline ProcXXVIII & 1 \\
\hline UndII & 1 \\
\hline UndXXVIII & 1 \\
\hline Total & 794 \\
\hline & \\
\hline
\end{tabular}

Table 9: SCM : Number of Table 10: AD : Number of times invoked in disputes

\begin{tabular}{|c|c|}
\hline \multicolumn{2}{|c|}{ SCM } \\
\hline Article & Frequency* \\
\hline $\mathbf{1}$ & 30 \\
\hline $\mathbf{2}$ & 21 \\
\hline $\mathbf{3}$ & 48 \\
\hline $\mathbf{4}$ & 6 \\
\hline $\mathbf{5}$ & 15 \\
\hline $\mathbf{6}$ & 16 \\
\hline $\mathbf{7}$ & 5 \\
\hline $\mathbf{9}$ & 1 \\
\hline $\mathbf{1 0}$ & 29 \\
\hline $\mathbf{1 1}$ & 20 \\
\hline $\mathbf{1 2}$ & 11 \\
\hline $\mathbf{1 3}$ & 4 \\
\hline $\mathbf{1 4}$ & 13 \\
\hline $\mathbf{1 5}$ & 11 \\
\hline $\mathbf{1 6}$ & 2 \\
\hline $\mathbf{1 7}$ & 9 \\
\hline $\mathbf{1 8}$ & 2 \\
\hline $\mathbf{1 9}$ & 18 \\
\hline $\mathbf{2 0}$ & 2 \\
\hline $\mathbf{2 1}$ & 12 \\
\hline $\mathbf{2 2}$ & 9 \\
\hline $\mathbf{2 5}$ & 1 \\
\hline $\mathbf{2 7}$ & 8 \\
\hline $\mathbf{2 8}$ & 2 \\
\hline $\mathbf{3 0}$ & 1 \\
\hline $\mathbf{3 2}$ & 19 \\
\hline Annex I & 2 \\
\hline Total & $\mathbf{3 1 7}$ \\
\hline & \\
\hline
\end{tabular}
times invoked in disputes

\begin{tabular}{|c|c|}
\hline \multicolumn{2}{|c|}{ AD } \\
\hline Article & Frequency* \\
\hline $\mathbf{1}$ & 52 \\
\hline $\mathbf{2}$ & 62 \\
\hline $\mathbf{3}$ & 54 \\
\hline $\mathbf{4}$ & 20 \\
\hline $\mathbf{5}$ & 53 \\
\hline $\mathbf{6}$ & 58 \\
\hline $\mathbf{7}$ & 22 \\
\hline $\mathbf{8}$ & 4 \\
\hline $\mathbf{9}$ & 37 \\
\hline $\mathbf{1 0}$ & 7 \\
\hline $\mathbf{1 1}$ & 24 \\
\hline $\mathbf{1 2}$ & 41 \\
\hline $\mathbf{1 5}$ & 6 \\
\hline $\mathbf{1 6}$ & 1 \\
\hline $\mathbf{1 7}$ & 3 \\
\hline $\mathbf{1 8}$ & 40 \\
\hline $\mathbf{1 9}$ & 1 \\
\hline Annex I & 5 \\
\hline Annex II & 30 \\
\hline Total & $\mathbf{5 2 0}$ \\
\hline & \\
\hline
\end{tabular}


Table 11: GATS : Number of times invoked in disputes

\begin{tabular}{|c|c|}
\hline \multicolumn{2}{|c|}{ GATS } \\
\hline Article & Frequency* \\
\hline I & 1 \\
\hline II & 9 \\
\hline III & 3 \\
\hline IV & 1 \\
\hline VI & 8 \\
\hline VIII & 2 \\
\hline XI & 1 \\
\hline XVI & 12 \\
\hline XVII & 17 \\
\hline XVIII & 4 \\
\hline XXIII & 3 \\
\hline TRP & 1 \\
\hline AnnMovPers & 1 \\
\hline AnnTelecoms & 1 \\
\hline Total & 64 \\
\hline
\end{tabular}

* The number of times various articles have been invoked in the Request for Consultations by the original

Complainants. An Article is counted only once even if referred to several times. Hence, if for instance SCM or AD, Arts. 3.1 and 3.2 have been both invoked, the Table counts this as one invocation of Art. 3. Equivalently, if for instance GATT Art. III.1 and III. 2 have been both invoked; the Table counts this as one invocation of Art. III.
Table 12: TRIPs: Number of times invoked in disputes

\begin{tabular}{|c|c|c|c|}
\hline \multicolumn{2}{|c|}{ TRIPs } & \multicolumn{2}{|c|}{ TRIPS } \\
\hline Article & Frequency $^{*}$ & Article & Frequency* \\
\hline 1 & 2 & 50 & 5 \\
\hline 2 & 6 & 51 & 2 \\
\hline 3 & 7 & 52 & 1 \\
\hline 4 & 4 & 53 & 1 \\
\hline 7 & 1 & 54 & 1 \\
\hline 8 & 1 & 55 & 1 \\
\hline 9 & 5 & 58 & 1 \\
\hline 10 & 2 & 59 & 2 \\
\hline 11 & 2 & 61 & 4 \\
\hline 12 & 2 & 62 & 2 \\
\hline 13 & 2 & 63 & 6 \\
\hline 14 & 5 & 65 & 14 \\
\hline 15 & 1 & 70 & 11 \\
\hline 16 & 3 & Total & 147 \\
\hline 17 & 1 & & \\
\hline 18 & 1 & & \\
\hline 19 & 1 & & \\
\hline 20 & 3 & & \\
\hline 21 & 1 & & \\
\hline 22 & 2 & & \\
\hline 24 & 2 & & \\
\hline 27 & 10 & & \\
\hline 28 & 6 & & \\
\hline 31 & 3 & & \\
\hline 33 & 3 & & \\
\hline 34 & 1 & & \\
\hline 39 & 3 & & \\
\hline 41 & 8 & & \\
\hline 42 & 5 & & \\
\hline 46 & 1 & & \\
\hline 49 & 2 & & \\
\hline
\end{tabular}


Tables 13a and 13b provide information on the invocation of five agreements (GATT, AD, SCM, GATS, TRIPs) broken down on the 16 possible constellations of complainant group/respondent group. The two Tables contain the same information, but exhibited in slightly different manner. In Table 13a the categorization is by country classification of the complainant, while in Table $13 \mathrm{~b}$ of the respondent.

Tables 13a and b show that, with regard to the GATT, G2 dominates as complainant in absolute numbers with 125 (bilateral) invocations, followed by 98 for IND, and 86 for DEV (we disregard LDC in this discussion since the impact of this groups is marginal). G2 has been the main target of GATT complaints, having been so almost three times more often than IND and DEV (171 invocations compared to 64 and 65 respectively) The role of the GATT for IND as a complainant and G2 as a respondent can be seen from the fact that complaints by IND against G2 account for $17 \%$ (60/347) of all GATT complaints and $61 \%$ of all GATT complaints by IND. IND has thus launched the most complaints against G2. G2 has also been frequently targeted by DEV and G2 with around $12 \%$ of GATT complaints have been between US - EU and DEV countries (42/347 and 40/347, respectively). 


\section{Table 13a: Invocation of agreements by complainant and respondent group*}

\begin{tabular}{|c|c|c|c|c|c|c|}
\hline Complainant & Respondent & AD & GATS & GATT & SCM & TRIPs \\
\hline \multirow{5}{*}{ BIC } & BIC & 1 & & 1 & & \\
\hline & DEV & 2 & & 3 & 1 & \\
\hline & G2 & 15 & & 30 & 11 & 3 \\
\hline & IND & 2 & & 3 & 3 & \\
\hline & Total & 20 & & 37 & 15 & 3 \\
\hline \multirow{5}{*}{ DEV } & BIC & 3 & & 5 & 1 & \\
\hline & DEV & 7 & 1 & 32 & & \\
\hline & G2 & 10 & 7 & 40 & 5 & \\
\hline & IND & 2 & 1 & 9 & & \\
\hline & Total & 22 & 9 & 86 & 6 & \\
\hline \multirow{5}{*}{ G2 } & BIC & 3 & 5 & 31 & 10 & 5 \\
\hline & DEV & 2 & & 20 & 5 & 4 \\
\hline & G2 & 8 & 4 & 42 & 18 & 10 \\
\hline & IND & 5 & 4 & 32 & 12 & 5 \\
\hline & Total & 18 & 13 & 125 & 45 & 24 \\
\hline
\end{tabular}

\begin{tabular}{|c|c|c|c|c|c|c|}
\hline \multirow{5}{*}{ IND } & BIC & & 1 & 9 & 5 & \\
\hline & DEV & 9 & & 10 & 1 & \\
\hline & G2 & 24 & 2 & 60 & 20 & 2 \\
\hline & IND & 1 & 1 & 19 & 3 & \\
\hline & Total & 34 & 4 & 98 & 29 & 2 \\
\hline
\end{tabular}

\begin{tabular}{|l|c|c|c|c|c|c|}
\hline \multirow{2}{*}{ LDC } & BIC & 1 & & \multicolumn{2}{|c|}{1} & \\
\hline & Total & 1 & & 1 & \\
\hline
\end{tabular}

* The number of times five major WTO Agreements have been invoked in Request for Consultations, by country group. Includes all bilateral disputes with both original member countries.

The prime target of AD complaints in among the country groups has been $\mathrm{G} 2$ with a total of 57 invocations or 60\% (57/95), where IND has been the most active invoker against G2 with 24 invocations out of 95 or $25 \%$. There have been relatively few invocations of TRIPs and the majority of such claims have been raised by G2 with a total of 24 or 83\% (24/26) of all TRIPs invocations. G2 have also been the main target of TRIPs with a total of 15 invocations or 52\% 
and then primarily by other G2, in practice disputes between EU - US. A similar pattern can be seen with respect to SCM complaints: 57\% (54/95) of all such complaints are directed against G2; here, G2 and DEV share the burden as complainants equally, accounting for, respectively, $19 \%(18 / 95)$ and $21 \%(20 / 95)$ of all complaints.

As we have already seen, there are very few GATS disputes. Examining the few invocations that have occurred, G2 has been the most targeted with a total of 13 or 50\% (13/26) of all GATS invocations. The main complainant group has been DEV with 7 invocations.

\section{Table 13b: Invocation of agreements by respondent and complainant group*}

\begin{tabular}{|c|c|c|c|c|c|c|}
\hline Respondent & Complainant & AD & GATS & GATT & SCM & TRIPs \\
\hline \multirow{6}{*}{ BIC } & BIC & 1 & & 1 & & \\
\hline & DEV & 3 & & 5 & 1 & \\
\hline & G2 & 3 & 5 & 31 & 10 & 5 \\
\hline & IND & & 1 & 9 & 5 & \\
\hline & LDC & 1 & & 1 & & \\
\hline & Total & 8 & 6 & 47 & 16 & 5 \\
\hline \multirow{5}{*}{ DEV } & BIC & 2 & & 3 & 1 & \\
\hline & DEV & 7 & 1 & 32 & & \\
\hline & G2 & 2 & & 20 & 5 & 4 \\
\hline & IND & 9 & & 10 & 1 & \\
\hline & Total & 20 & 1 & 65 & 7 & 4 \\
\hline \multirow{5}{*}{ G2 } & BIC & 15 & & 30 & 11 & 3 \\
\hline & DEV & 10 & 7 & 40 & 5 & \\
\hline & G2 & 8 & 4 & 42 & 18 & 10 \\
\hline & IND & 24 & 2 & 60 & 20 & 2 \\
\hline & Total & 57 & 13 & 172 & 54 & 15 \\
\hline \multirow{5}{*}{ IND } & BIC & 2 & & 3 & 3 & \\
\hline & DEV & 2 & 1 & 9 & & \\
\hline & G2 & 5 & 4 & 32 & 12 & 5 \\
\hline & IND & 1 & 1 & 19 & 3 & \\
\hline & Total & 10 & 6 & 63 & 18 & 5 \\
\hline
\end{tabular}


* The number of times five major WTO Agreements have been invoked in Request for Consultations, by country group. Includes all bilateral disputes with both original member countries.

\section{Table 14: Invocation of agreements by third party group}

\begin{tabular}{|c|c|c|c|c|c|c|}
\hline Third party & AD & GATS & GATT & SCM & TRIPs & Total \\
\hline BIC & 18 & 0 & 51 & 14 & 6 & 89 \\
\hline DEV & 17 & 18 & 193 & 52 & 7 & 287 \\
\hline G2 & 16 & 8 & 118 & 28 & 12 & 182 \\
\hline IND & 30 & 3 & 304 & 68 & 47 & 452 \\
\hline LDC & 0 & 0 & 4 & 4 & 0 & 8 \\
\hline Total & 81 & 29 & 670 & 166 & 72 & 1018 \\
\hline
\end{tabular}

Table 14 identifies the agreements being invoked in cases where third parties have joined the process. As expected, GATT issues have been unparalleled in attracting countries to join: 640 third parties or $63 \%$ of all third parties have appeared in cases where the GATT has been invoked. IND has been quite active in this process.

\section{Winners and losers of legal claims}

The data set contains information on the legal claims made by the parties and on whether adjudicating bodies have accepted these claims or not. In this Section, we will take a brief look at some of these data. ${ }^{3}$

A few preliminary comments are required. The "unit of account” in the analysis is legal claims, as defined in the WTO case law on Art. 6.2 DSU: a legal claim comprises a factual matter and the legal provision that it allegedly violates. We are only concerned with the panel stage, and whether claims are won or not. We follow the evolution of the EU membership in the sense that up to January 1, $2004 \mathrm{EU}$ is EU-15, after that date EU-25. In 2007, Bulgaria and Romania

\footnotetext{
${ }^{3}$ Hoekman et al (2007) provides a more detailed account, but based on older data.
} 
joined, further expanding EU to EU-27. Both have previously been active in the WTO dispute settlement, Bulgaria as third party during consultations and Romania as defendant.

There are in total 176 bilateral disputes with the definition just mentioned, involving a total of 2,979 legal claims. Table 15 shows how these are distributed across pairs of complaining and responding Members, grouped by their country status. The IND group has raised almost half (42\%) of all the claims but only been the target of $15 \%$ of all claims. G2 seems to have been the most targeted country group where 75\% of all claims raised have been against G2. However, G2 is only second to IND in raising claims where one third (27\%) of all claims has been raised by G2. BIC and DEV have almost equal share in raising claims with around $15 \%$ of all claims. Though DEV have been more targeted, this is to be expected since there are more countries belonging to the DEV group than BIC.

Table 16 depicts for each pair (complainant group, respondent group) the average number of claims. There is significant variation, both for each complainant group across respondents, and for each respondent group across complainants. At the lower end, a G2 complaint against a DEV country on average involves around 4 claims, while an IND complaint against a G2 country on average comprises almost 29 claims. Note however, that the average number of claims between DEV complainant and IND respondent is 52 claims but comprise of only two cases and BIC complaint against DEV country is 31 claims but this reflects only one case. So care should be taken with these averages.

\section{Table 15: Distribution of number of legal claims by group pairing}

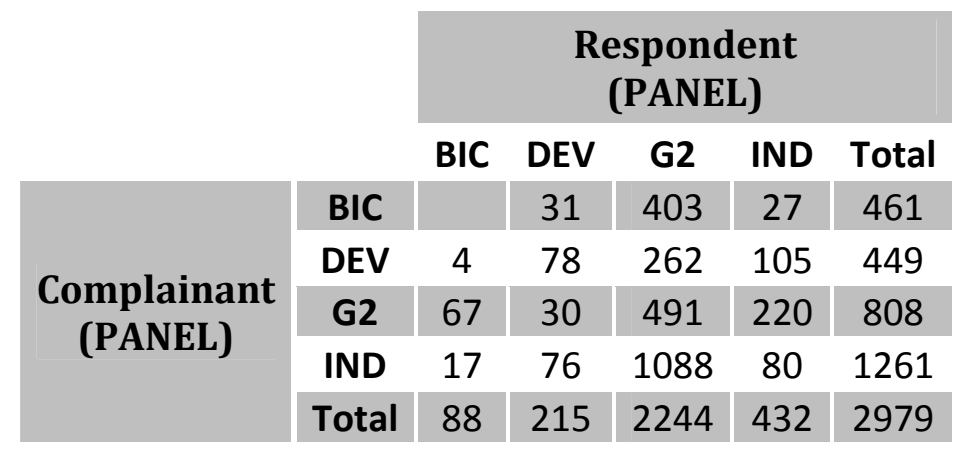

Table 16: Average number of claims within each group pairing 


\begin{tabular}{|c|c|c|c|c|c|}
\hline & \multicolumn{4}{|c|}{$\begin{array}{l}\text { Respondent } \\
\text { (PANEL) }\end{array}$} \\
\hline & & BIC & DEV & G2 & IND \\
\hline \multirow{4}{*}{$\begin{array}{l}\text { Complainant } \\
\text { (PANEL) }\end{array}$} & BIC & & 31.0 & 20.2 & 9.0 \\
\hline & DEV & 4.0 & 15.6 & 11.9 & 52.5 \\
\hline & G2 & 6.1 & 3.8 & 18.9 & 9.2 \\
\hline & IND & 8.5 & 12.7 & 28.6 & 11.4 \\
\hline
\end{tabular}

The distribution of the claims across agreements is shown in Table 17. Disregarding the GATT provision the majority of claims are under the three contingent protection instruments AD, CVD, and SG.

Table 17: The distribution of claims across agreements/provisions

\begin{tabular}{l|c|c|}
\hline \multicolumn{2}{|l}{ Agreements/provisions } & No. of claims \\
\hline AD & 841 \\
\hline AG & 47 \\
\hline ATC & 13 \\
\hline DSU: $\quad 3.7$ & 2 \\
\hline GATS & 30 \\
\hline GATT: & I & 26 \\
\hline GATT: & II & 117 \\
\hline GATT: & III & 102 \\
\hline GATT: & VI & 88 \\
\hline GATT: & X & 63 \\
\hline GATT: & XI & 27 \\
\hline GATT: & XIII & 12 \\
\hline GATT: & XIX & 69 \\
\hline GATT: & XX & 37 \\
\hline SCM & & 401 \\
\hline SG & & 580 \\
\hline SPS & & 313 \\
\hline TBT & & 14 \\
\hline TRIPs & XVI & 70 \\
\hline WTO: & & 33 \\
\hline
\end{tabular}


The outcomes of the cases are classified in the data set on the basis of the findings by WTO adjudicating bodies as they appear in the 'Conclusions and Recommendations' Section of each panel report. We classify outcomes into three groups: (1) claims where the complainant prevailed; (2) claims where the defendant prevailed; and (3) a residual group of claims where the outcome is unclear. The last category has been included despite the fact that in principle a panel should either find for or against a claim by a complainant. But practice has made inclusion of this third category a necessity: a typical example would be exercise of judicial economy by panels.

For Table 18, the average number of successful claims is calculated by simply dividing the total number of successful claims (“wins”) for a given group by the total number of claims made by the group for a specific pairing. It can be noted that overall success rates are remarkably similar for the four active groups: when acting as complainants, G2, IND, BIC and DEV win around $60 \%$ of the claims they advance, when calculated as a share of all the claims each group makes. Similarly, the total win percentage for the four complainant groups ranges between $53 \%$ and $64 \%$ of all the claims they advance. But the Table also reveals a significant variability across different complainant-respondent constellations. Most successful are G2 and DEV countries when complaining against DEV, winning around $83 \%$ of the claims. At the other end of the spectrum we find that the DEV group wins less than $29 \%$ of the claims that its members advance against IND.

\section{Table 18: Average percentage successful claims by group pairing, based on the sum of all claims for the pairing}

\begin{tabular}{c|c|c|c|c|c|c|} 
& & & \multicolumn{4}{c|}{$\begin{array}{c}\text { Respondent } \\
\text { (PANEL) }\end{array}$} \\
\hline & \% & BIC & DEV & G2 & IND & Total \% wins \\
\hline & BIC & & 64.5 & 54.3 & 37.0 & 54.0 \\
\hline $\begin{array}{c}\text { Complainant } \\
\text { (PANEL) }\end{array}$ & DEV & 0 & 83.3 & 56.1 & 28.6 & 53.9 \\
\hline & G2 & 71.6 & 83.3 & 61.9 & 62.7 & 63.7 \\
\hline & IND & 82.4 & 47.4 & 54.3 & 68.8 & 55.2 \\
\hline
\end{tabular}




\section{The panelists}

Table 19 provides data on the nationality of individuals that have served as panelists (chair + non chair) in the 199 Panels in the data set; since each panel is composed by three panelists - the data set contains a total of 597 panelist-slots. A striking feature in this context is that individuals originating in IND and DEV have appeared as panelists (chair, non chair) in 489/597 times, that is, in almost $82 \%$ of all times. 51 different nationalities have been represented, which means that more than two-thirds of all WTO Members have never had a panelist. On 59 occasions a G2 citizen has acted as panelist (chairman + non chairman). This is less than $10 \%$ of all panelists used. The US tops the list in this category with 14 times (9 of which chair). US citizens account for $14 / 59$ panelists, that is, less than $25 \%$ of the total G2 representation. Germany comes second with 10 (2 chair), and Sweden third with 9 (8 chair) panelists.

$54 \%$ of all panelists come from IND, the largest representation in this context. New Zealand tops the list with 57 (21 chair), and Switzerland comes second with 48 (24 chair). Australia is third with 34 (3 chair). 27\% of all panelists come from DEV. Chile tops the list with 25 (of which 3 chair) followed by South Africa with 22 (6 chair) and Venezuela with 18 (4 chair). 9\% of all panelists come from India or Brazil (BIC) where India has been most frequent as panelist with 30 (of which 10 chair) closely followed by Brazil with 22 (5 as chair).

Table 20 shows that the composition of panels has been decided exclusively by agreement between the parties to the dispute on 73 (of a total of 199) occasions. Much more common has been for the DG to appoint the panel as per Art. 8.7 DSU; this has occurred on 126 occasions. This does not mean, however, that on each of these occasions the DG has appointed all three panelists; it could well be the case that the DG appointed only two, or even one panelist. 


\section{Table 19: Distribution of panelists by nationality and function}

\begin{tabular}{|c|c|c|c|c|c|}
\hline Country & Chair & Non-Chair & Country & Chair & Non-Chair \\
\hline Austria & 0 & 1 & Brazil & 5 & 17 \\
\hline Belgium & 1 & 4 & India & 10 & 20 \\
\hline Finland & 1 & 4 & Total BIC & 15 & 37 \\
\hline France & 0 & 2 & & & \\
\hline Germany & 2 & 8 & & & \\
\hline Ireland & 0 & 3 & Country & Chair & Non-Chair \\
\hline Italy & 0 & 1 & Argentina & 4 & 7 \\
\hline Netherlands & 0 & 1 & Chile & 3 & 22 \\
\hline Sweden & 8 & 1 & Colombia & 5 & 9 \\
\hline United States & 9 & 6 & Costa Rica & 4 & 1 \\
\hline United Kingdom & 0 & 7 & Ecuador & 0 & 3 \\
\hline Total G2 & 21 & 38 & Egypt & 7 & 4 \\
\hline & & & Indonesia & 0 & 3 \\
\hline Country & Chair & Non-Chair & Jamaica & 0 & 3 \\
\hline Australia & 3 & 31 & Malaysia & 0 & 2 \\
\hline Bulgaria & 0 & 1 & Mauritius & 0 & 2 \\
\hline Canada & 10 & 22 & Morocco & 2 & 0 \\
\hline Czech Republic & 4 & 7 & Pakistan & 3 & 7 \\
\hline Hong Kong - China & 16 & 3 & Panama & 0 & 1 \\
\hline Hong Kong & 0 & 2 & Philippines & 3 & 4 \\
\hline Hungary & 0 & 2 & South Africa & 6 & 16 \\
\hline Iceland & 8 & 2 & Thailand & 0 & 8 \\
\hline Israel & 0 & 11 & Venezuela & 4 & 14 \\
\hline Japan & 1 & 12 & Total DEV & 53 & 112 \\
\hline Switzerland & 24 & 24 & & & \\
\hline Taiwan & 0 & 1 & & & \\
\hline Total IND & 110 & 211 & & Frequency & Percent (\%) \\
\hline & & & BIC & 52 & 8.7 \\
\hline & & & DEV & 165 & 27.6 \\
\hline & & & $\mathbf{G 2}$ & 59 & 9.8 \\
\hline & & & IND & 321 & 53.8 \\
\hline & & & Total & 597 & 99.9 \\
\hline
\end{tabular}




\section{Table 20: Composition of panels by the parties or the DG, and the respondent's country status}

\begin{tabular}{|c|c|c|c|c|c|c|}
\hline \multicolumn{7}{|c|}{ Respondent } \\
\hline & BIC & DEV & G2 & IND & Total & \% Total \\
\hline DG & 15 & 17 & 71 & 23 & 126 & 63.3 \\
\hline Parties & 4 & 13 & 38 & 18 & 73 & 36.7 \\
\hline Total & 19 & 30 & 109 & 41 & 199 & 100.0 \\
\hline
\end{tabular}

Table 21 shows the propensity for panelists to serve more than once. As can be seen, a total of 269 individuals have served as panelist in 199 panel proceedings so far. 133 individuals served only panelist, whereas 138 individuals served at least twice. Hence, more than $50 \%$ of the panelists have served more than once. 24 out of 269, that is, 9\%, have served 5 times or more. The record is held by Mohan Kumar from India, who served on 14 occasions, followed by Michael Cartland (Hong Kong, China, 11) and Wilhelm Meier (Switzerland, 11). Panelists who have served 10 times are Claudia Orozco (Colombia), Crawford Falconer (New Zealand), Enie Neri de Ross (Venezuela), Maamoun Abdel-Fattah (Egypt), Margaret Liang (Singapore), Ole Lundby (Norway) and Peter Palecka (Czech Republic). 
Table 21: Repeat panelists

\begin{tabular}{ccccc|c}
\hline $\begin{array}{c}\text { Number of panels that the } \\
\text { panelist has served on }\end{array}$ & Chair & Non-Chair & $\begin{array}{c}\text { Total no. of } \\
\text { panelists }\end{array}$ & Cumulative \\
\hline $\mathbf{1}$ & 38 & 93 & 131 & 131 \\
\hline $\mathbf{2}$ & 16 & 46 & 62 & 124 \\
$\mathbf{3}$ & 4 & 26 & 30 & 90 \\
$\mathbf{4}$ & 9 & 13 & 22 & 88 \\
$\mathbf{5}$ & 3 & 5 & 8 & 40 \\
$\mathbf{6}$ & 3 & 3 & 6 & 36 \\
$\mathbf{7}$ & 3 & & 3 & 21 \\
$\mathbf{8}$ & 2 & 2 & 4 & 32 \\
\hline $\mathbf{1 0}$ & & 1 & 1 & 10 \\
\hline $\mathbf{1 1}$ & 1 & & 1 & 11 \\
\hline $\mathbf{1 4}$ & & 1 & 1 & 14 \\
\hline
\end{tabular}




\section{The duration of the process}

Table 22 provides some simple data on the duration of the various stages of the DS process. Starting with the bilateral leg of the process -- consultations -- we observe that their average length is 164.6 days. Recall that 60 days after the initiation of the consultation process, the complainant can request establishment of a Panel, if consultations up to that point were unsuccessful. Since the length of the consultations process depends solely on the will of the consulting parties, one cannot talk of delays etc. Moreover, complainants might prefer to invest additional time at the consultation-stage if they are relatively sure that they can reach a conclusion at this stage and avoid going through the remaining cumbersome process (panel, AB, compliance panel, compliance $\mathrm{AB}$, arbitration to define reasonable period of time, arbitration to decide on the request for countermeasures). Leaving the consultation-stage aside, one can compare the statutory deadlines and the de facto duration of all other stages in the WTO DS process. One should be careful, nevertheless, not to attribute responsibility for delays to the institution without further examination: the process can slow down because of the parties as well.

\section{Table 22: Average length of various phases of the DS process}

\begin{tabular}{cccl}
\hline Average length of process & Days & $\begin{array}{c}\text { Statutory } \\
\text { deadline }\end{array}$ & \multicolumn{1}{c}{ Explanation } \\
\hline Consultations & $\begin{array}{c}164.6 \text { days } \\
(5.5 \text { months })\end{array}$ & $\begin{array}{c}60 \text { days } \\
(2 \text { months })\end{array}$ & $\begin{array}{l}\text { From the date of Request for } \\
\text { Consultations until the date the } \\
\text { Panel was established. }\end{array}$ \\
\hline Panel & $\begin{array}{c}444.9 \text { days } \\
(14.7 \text { months })\end{array}$ & $\begin{array}{c}180 \text { days } \\
(6 \text { months })\end{array}$ & $\begin{array}{l}\text { From the date the Panel was } \\
\text { established until the date of the } \\
\text { circulation of the Panel Report. }\end{array}$ \\
\hline Appellate Body & $\begin{array}{c}90.3 \text { days } \\
(3 \text { months })\end{array}$ & $\begin{array}{c}\text { From the date of the Notice of } \\
(2 \text { months })\end{array}$ & $\begin{array}{l}\text { Appeal until the date of the } \\
\text { circulation of the Appellate Body } \\
\text { report. }\end{array}$ \\
\hline RPT when agreed bilaterally & 9.29 months & & $\begin{array}{l}\text { The average RPT awarded by the } \\
\text { arbitrator in the awards circulated. }\end{array}$ \\
\hline RPT when awarded by arbitrator & 11.7 months & $\begin{array}{l}\text { Total length of agreed period } \\
\text { between parties of RPT during which } \\
\text { implementation must occur. }\end{array}$ \\
\hline
\end{tabular}




\begin{tabular}{|c|c|c|c|}
\hline Compliance Panel & $\begin{array}{l}253.0 \text { days } \\
\text { (8.3 months) }\end{array}$ & $\begin{array}{c}90 \text { days } \\
\text { (3 months) }\end{array}$ & $\begin{array}{l}\text { From the date of the request to } \\
\text { establish a first compliance panel } \\
\text { until the date of circulation of the } \\
\text { Compliance Panel Report. }\end{array}$ \\
\hline AB Compliance & $\begin{array}{c}87.6 \text { days } \\
\text { (2.9 months) }\end{array}$ & & $\begin{array}{l}\text { From the date of the first Notice of } \\
\text { Appeal until the date of circulation } \\
\text { of the Appellate Body compliance } \\
\text { report. }\end{array}$ \\
\hline
\end{tabular}

\section{Table 23: Duration of the consultation stage (mean number of days) by complainant and respondent group}

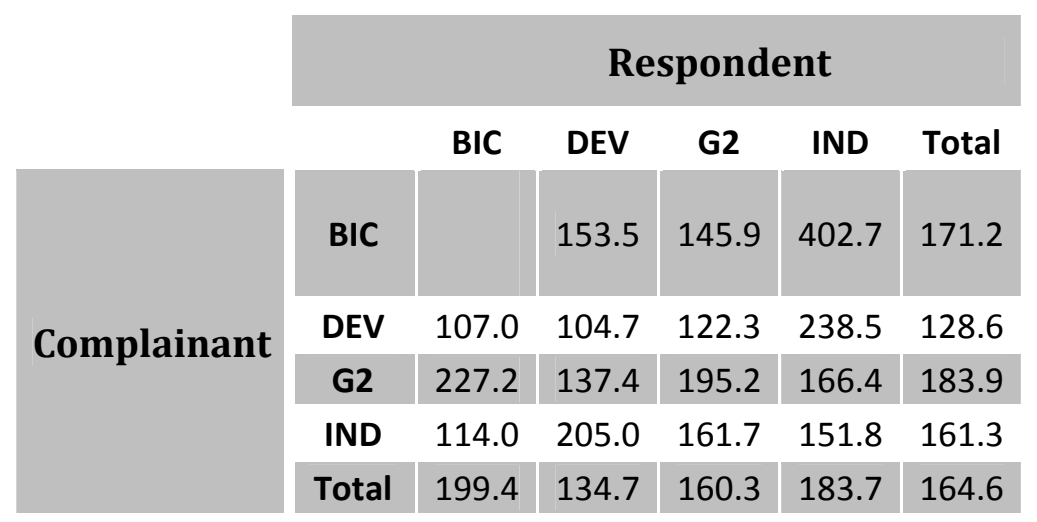

Breaking down the average length of consultations by country group pairings, it does not vary much between group pairs. Countries with disputes that proceed to the Panel stage remain in consultations around 5 to 6 months. The only exception is when BIC has initiated dispute with IND, where the average duration has been around 13 months for the three cases in this group.

Figures 2-4 display the variation in terms of process length for the consultation stage, the Panel stage, and the AB stage, respectively. In each Figure the disputes are ordered vertically according to increasing process length.

Turning to the Panel stage, the statutory duration of the panel process is 6 months or around 180 days. This deadline for completion of the process can be extended to 9 months (around 270 days), if need be, but the DSU seems to suggest (Art. 12.9) that this period should not be extended any further. The average panel process of the disputes reflected in the data is 445 days, 
that is, around 15 months. The data underlying Figure 3 shows that the panel process had been completed within the statutory limits in only 10 instances. At the other end there are 42 disputes with duration of over 500 days.

\section{Figure 2: Duration of the consultation stage (days)}

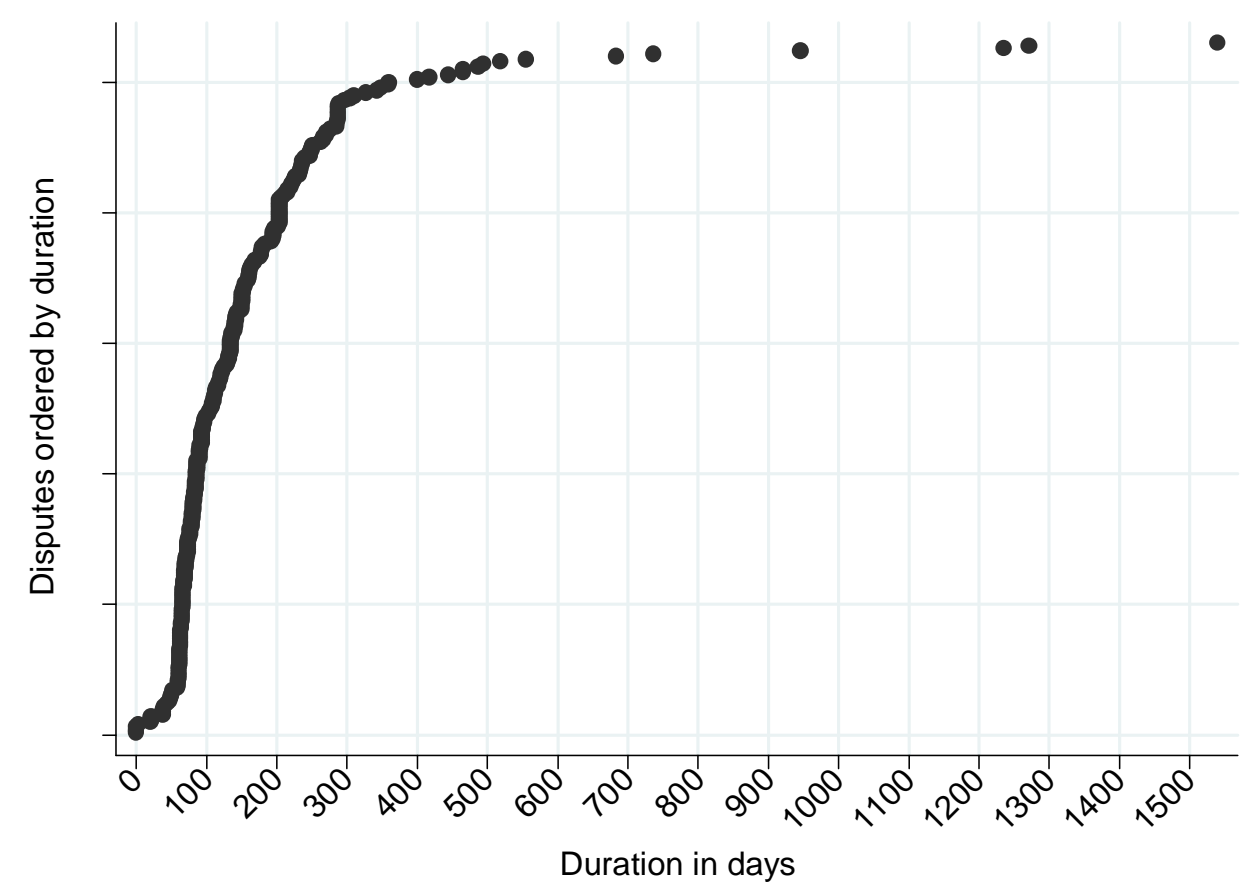

Finally, examining the duration of the Appellate Body (AB) process, we first note that the statutory deadline for its completion is 60 days, but with the possibility to extend it to 90 days. De facto, the $\mathrm{AB}$ manages to complete its work within this deadline: the average duration is 90.3 days. On 113 out of 127 occasions, that is, $89 \%$ of the total number, the AB completed its work within 91 days. In 6 cases the AB completed its work within the statutory deadline of 60 days and there are only 13 disputes where the AB process exceeded 90 days. 
Figure 3: Duration of Panel stage (days)

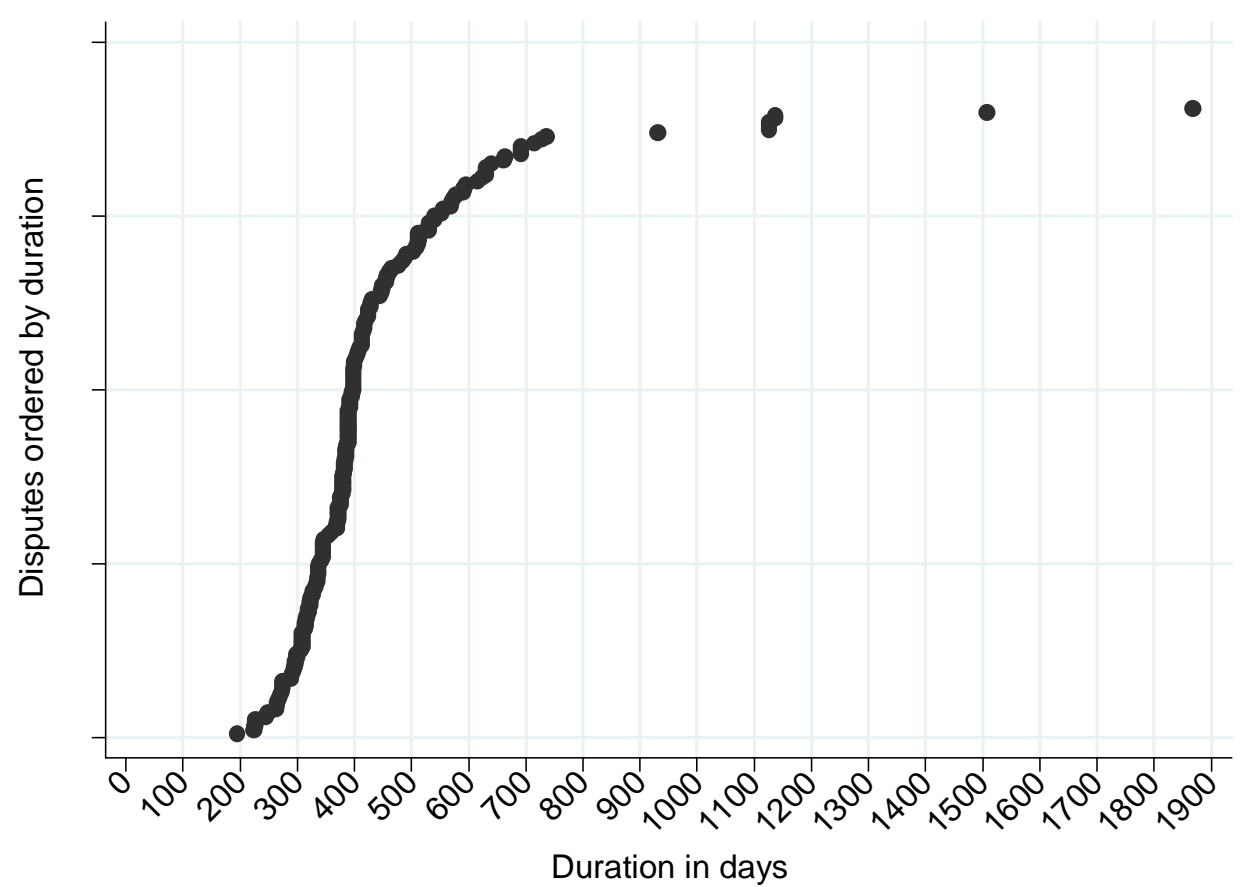

Figure 4: Duration of the AB stage (days)

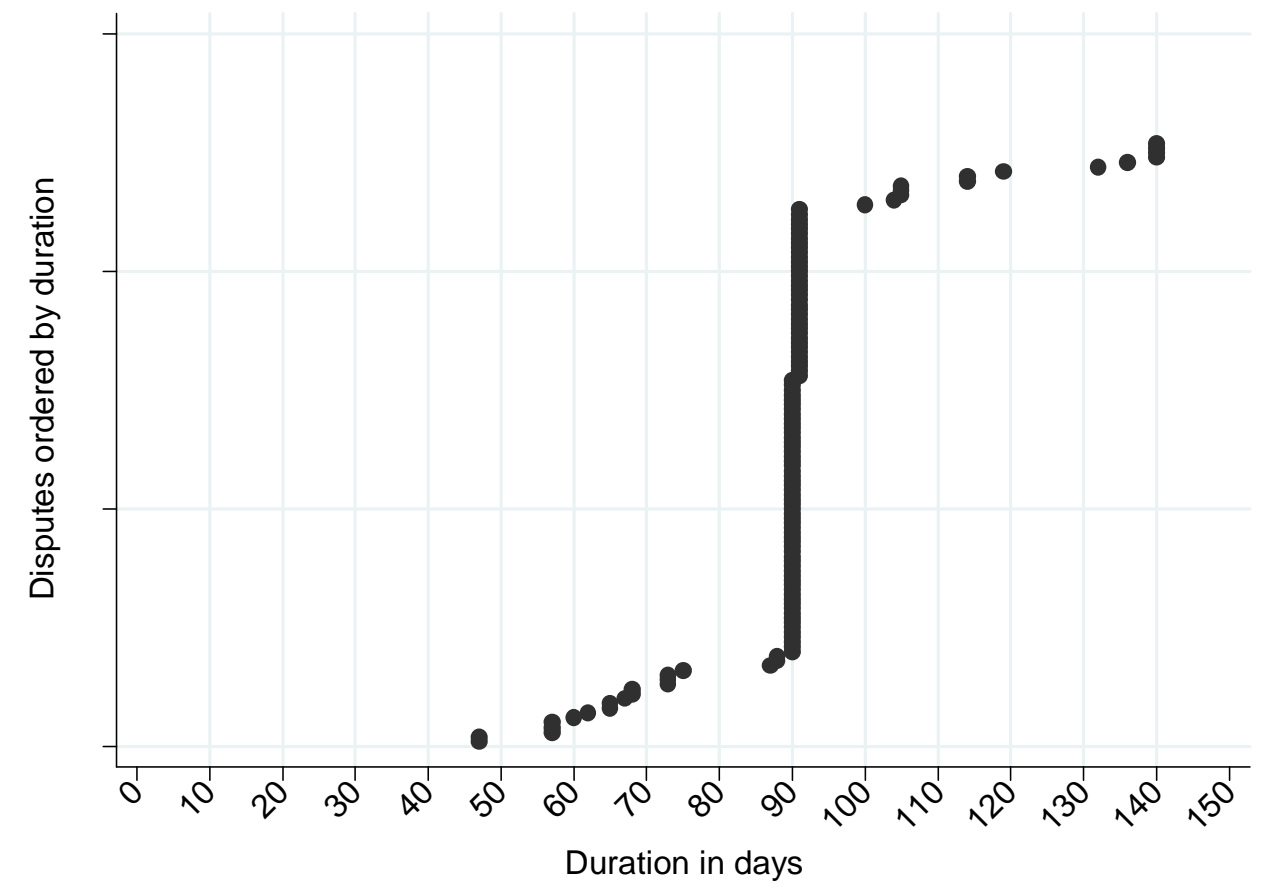


Compliance panels (Art. 21.5 DSU) have to observe a statutory 90 days-deadline. They can, however, take a longer time, if need be. Contrary to what is the case under Art. 12.9 DSU, Art. 21.5 DSU does not provide for a maximum delay of the process. Compliance panels enjoy some flexibility when deciding the time for completion of the process. In practice, they take on average 253 days or around 8 months to complete their work. The AB completes its work even faster when discussing an appeal against a compliance panel report (Art. 21.5 DSU) than when adjudicating an appeal against an ordinary panel report: on average it does so within 88 days (around 3 months).

Finally, Table 22 also yields information on the average reasonable period of time (RPT) for implementation of the WTO adjudicating bodies' recommendations/suggestions. The RPT has in practice been determined either through agreement between the parties, or through recourse to an Arbitrator. There are no statutory deadlines imposing a time-frame during which parties to a dispute must reach an agreement as to the extent of the RPT, so the type of analysis undertaken above cannot be repeated for the bilateral determination of RPTs. There is a statutory deadline that the Arbitrator must respect (Art. 21.3c). This is not, however, an interesting feature of the process and in what follows we focus on the length of the RPT that the Arbitrator has awarded, rather than ask the question whether he/she has respected the statutory deadlines when determining its extent. It should be noted that the DSU (Art. 21.3c) provides a guideline to the Arbitrator when it comes to fixing the RPT: it should not be longer than 15 months. The DSU acknowledges, however, that the RPT can extend beyond 15 months if need be.

What can be done, however, is to compare the awarded RPT depending on whether it is determined through a bilateral agreement or through arbitration. As reported in the Table, the average length of bilaterally RPT is 9 months, while the average RPT fixed by the Arbitrator is 12 months. Hence, the average RPT is significantly shorter when determined by the parties than by the Arbitrator. 


\section{Instead of conclusions}

In the above we have presented a number of observations concerning various aspects of the DS system, as it has left an imprint in our data set. We have merely displayed this data, without any attempt at statistically explaining why the data looks the way it does. Nor have we presented any benchmark against which to compare whether countries are over- or under-represented in the system, or whether it is working satisfactory in other respects. It is therefore impossible to draw any firm conclusions from the above - it is only meant to serve as food for further thought. There are a couple of features that we find somewhat striking in this regard.

A first observation, and there is no surprise here, is the almost complete absence of the large LDC group. One could add to this group a large number of countries in DEV that have never been active neither as participants in disputes, nor in the adjudication process. It is therefore hard to escape the conclusion that a large fraction of the WTO Membership is passive as it comes to the WTO DS system.

A second observation is the, to our mind, surprisingly high participation rate by the DEV group. It should be recalled here that we have classified as IND several countries that would in the WTO be treated as developing countries; this includes, for instance, Hong Kong - China, Korea, Mexico and Turkey. These are all countries that are relatively active in the DS system. Despite having excluded them from the DEV group, the latter nevertheless appear as a significant player, the way this is measured here.

Our third observation is a defence for introducing the BIC group: the three countries are 'officially' developing countries but are now active members (two of them, Brazil, India) of the new Quad (along with the EU, and the US) whereas all three join the G2 in the informal G5 group, which has been playing a prominent role in the negotiation of the Doha round. In dispute settlement, their numbers, as reflected many times in this paper, differ (and sometimes, dramatically) from those of DEV countries. The BIC group is emerging as a key player in the WTO DS procedures. 
Our final, observation is that the G2 group is less dominant as complainant than we would have guessed. It tends to be much more often the subject of complaints, than a complaining party, and G2 has had a very low share of all panelists. This is not to take a stand on the "weight" of these countries in the organization, but just to point out how our numbers come out. 


\section{ANNEX: List of abbreviations employed in the paper}

$\mathrm{AD}$

AG

ATC

ChinaAA

CV

EnC

GATS

GATT

GPA

IL

ILA

MDTruth

ROO

SG

SCM

SPS

TBT

TRIMs

TRIPs

TRP

1979Und
Agreement on Implementation of Art. VI of GATT 1994 (antidumping)

Agreement on Agriculture

Agreement on Textiles and Clothing

China Accession Agreement

Agreement on Implementation of Art. VII of GATT 1994 (customs valuation)

Enabling Clause

General Agreement on Trade in Services

General Agreement on Tariffs and Trade

Agreement on Government Procurement

Illustrative List (annexed to the TRIMs)

Agreement on Import-Licensing Procedures

Ministerial Decision Regarding Cases Where Customs Administrations

Have Reasons To Doubt The Truth Or Accuracy Of Declared Value Agreement on Rules of Origin

Agreement on Safeguards

Agreement on Subsidies and Countervailing Measures

Agreement on the Application of Sanitary and Phyto-Sanitary Measures

Agreement on Technical Barriers to Trade

Agreement on Trade-Related Investment Measures

Agreement on Trade-Related Intellectual Property Rights

Telecoms Reference Paper (GATS)

1979 Understanding Regarding Notification, Consultation, Dispute Settlement and Surveillance 